\title{
Plant tissue culture of Nicotiana tabacum cv. TAPM 26 and its minimum inhibition against herbicide-Dalapon
}

\author{
Karwan Talaat Mohammed ${ }^{1}$, Muhamad Arshad Javed ${ }^{1}$, Fahru Huyop ${ }^{1}$, Yilmaz Kaya ${ }^{*}, 1,2,3$ \\ ${ }^{1}$ Department of Biocience, Faculty of Sciences, Universiti Teknologi Malaysia, 81310 Skudai, Johor, Malaysia \\ 2 Department of Biology, Faculty of Science, Kyrgyz-Turkish Manas University, 720038 Bishkek, Kyrgyzstan, \\ yilmaz.kaya@manas.edu.kg, ORCID: 0000-0003-1506-7913 \\ ${ }^{3}$ Agricultural Biotechnology Department, Faculty of Agriculture, Ondokuz Mayis University, Samsun, Turkey. \\ yilmaz.kaya@omu.edu.tr
}

\section{A B S T R A C T}

Current study is to establish a basic plant tissue culture of Nicotiana tabacum TAPM 26 and test the plant tissue on resistancies against 2,2 DCP an active ingredient in herbicide-Dalapon. During micropropagation, the surface sterilization method was ascertained on seeds of tobacco. $\mathrm{HgCl} 2$ was used to disinfect tobacco seeds at different concentrations $\left(0.05 \mathrm{gL}^{-1}, 0.2 \mathrm{gL}^{-1}, 0.5\right.$ $\mathrm{gL}^{-1}$ and $1.0 \mathrm{gL}^{-1}$ ) within three minutes. About $70 \%$ seeds were survived when exposed to 0.05 $\mathrm{gL}^{-1}$ of $\mathrm{HgCl} 2$, whereas, no seeds were germinated when sterilized at concentrations above 0.05 $\mathrm{gL}^{-1}$ of $\mathrm{HgCl}$. To optimize an efficient protocol of shoots and callus formation during in vitro regeneration, explant types and plant growth were studied. Growth regulators NAA $\left(0.1 \mathrm{mgL}^{-1}\right.$, $0.2 \mathrm{mgL}^{-1}, 0.5 \mathrm{mgL}^{-1}, 1.0 \mathrm{mgL}^{-1}$ and $\left.2.0 \mathrm{mgL}^{-1}\right)$ and BAP $\left(1.0 \mathrm{mgL}^{-1}, 2.0 \mathrm{mgL}^{-1}, 3.0 \mathrm{mgL}^{-1}\right.$ and $4.0 \mathrm{mgL}^{-1}$ ) were used. The explants types were one month old leaves and two weeks old cotyledons. The maximum numbers of shoots per explants were obtained from cotyledon with combination $0.1 \mathrm{mgL}^{-1} \mathrm{NAA}$ and $1.0 \mathrm{mgL}^{-1} \mathrm{BAP}$. The highest callus fresh weight was achieved when NAA $0.5 \mathrm{mgL}^{-1}$ with BAP $1.0 \mathrm{mgL}^{-1}$ after four weeks. Thus, the highest number of shoots produced per explants from leaves culture on the MS media containing $0.2 \mathrm{mgL}^{-1} \mathrm{NAA}$ and 4.0 $\mathrm{mgL}^{-1} \mathrm{BAP}$. The best callus fresh weight was obtained with combination of $1.0 \mathrm{mgL}^{-1} \mathrm{NAA}^{-1}$ and $1.0 \mathrm{mgL}^{-1}$ BAP by using leaves explant. Finally, Dalapon $\left(5 \mathrm{gL}^{-1}, 10 \mathrm{gL}^{-1}, 15 \mathrm{gL}^{-1}\right.$ and $\left.20 \mathrm{gL}^{-1}\right)$ were applied onto leaves and cotyledon cultures of $N$. tabacum to check on the minimum concentration of inhibition. The minimum concentration of inhibition of leaves and cotyledon cultures of $N$. tabacum was at $5 \mathrm{gL}^{-1}$ of 2,2DCP but not at $10 \mathrm{gL}^{-1}, 15 \mathrm{gL}^{-1}$ and $20 \mathrm{gL}^{-1}$. This investigation will shed alight for future studies on transgenic tobacco resistant against Dalapon

\section{ARTICLE INFO}

Research article

Received: 12.12 .2020

Accepted: 19.03.2021

Keywords:
seeds sterilization,
NAA,
BAP,
callus formation,
shoot regeneration,
Dalapon,
2,2 DCP
${ }^{*}$ Corresponding author

Keywords:

seeds sterilization,

$N A A$

Dalapon,

Corresponding author

\section{Introduction}

Plant tissue culture refers to the set of methods designed for growth and microprogation of an explant that grown on a specialized nutrient solutions called standard media in the aseptic condition $[1,2]$. Tobacco (Nicotiana tabacum L.) is one of the most valuable cash crops, which belongs to the Solanaceae family [3]. Tobacco plant is an indigenous plant species found in tropical South America, South West Africa and the South Pacific $[4,5]$. It has been cultivated since preColombian times and separated to the world $[6,7]$. Tobacco was always used as a model plant performed a main provision in advancement of plant tissue culture, transgenic research and genetic engineering over the past few decades because of its scientific uniqueness $[8,9,10]$. Tobacco is a valuable commercial plant and has become an important tool for the advancing production methods of a recombinant vaccines, pharmaceutical compounds, commercial enzymes, proteins and antibodies $[11,12,13]$. The first research on the creation of plant based vaccine was successfully achieved in tobacco with the hope of developing a less expensive product [14, 15, 16].

In plant tissue culture method, development of an efficient micropropagation technique involved in removal of plant pathogens from an infected explant source. In addition, this technique can also enhance in plant breeding systems to create new cultivars with higher profit, resistance to pathogens, pest resistance as well as weed resistance $[17,2,18]$. Tobacco has also been a favorable medium for studies of inheritance and evolution [11, 19]. 
The genus Nicotiana comprises of an approximately 70 species, in which Nicotiana tabacum is the most well-known in businesses as tobacco product and in academic for science development studies [20,21]. The physiology and genetics of the Nicotiana genus has been widely explored for example its ability to regenerate into a specilised tissues to form a fully grown living organism from its de-differentiated cells. Nicotiana tabacum was always selected for developing of genetically modified plant model having functional of foreign genetic materials [22, 23, 24, 25, 26, 49].

The in-vitro propagation consists of numerous steps such as selection of explants, aseptic culture establishment, and multiplication of propagules, rooting and acclimatization of plantlets. However, the most critical and important step is surface sterilization for seeds or explants for culturing at sterile environment. Surface sterilization is a technique to make seeds or explants free from contamination before culturing on nutrient media [27,28,29,30,31]. Direct shoot propagation using leaves segment and cotyledons have been successfully established using tobacco [32]. On the other hand, production of regeneration plant through indirect organogenesis is also another possibility to contribute tobacco genomic enhancement $[33,34]$. Callus stage is widely studied in tissue culture protocols to present new desirable cultivars and generating genetically modified plants to achieve some new traits such as pesticide or herbicide resistance product $[35,17,36]$.

Growth regulators can be defined as a small organic molecule that elicits a physiological response at very low concentration and its important components in the tissue culture media to enhance and developed pathways in plant cells product $[37,38]$. The concentrations of growth regulators are very critical for the control of enlargement and morphogenesis [39]. However, different type of tissue or organs considerably required various amount of substance depends on their uptake and endogenous levels [40]. The most significant classes of growth regulators are auxins and cytokinins. Auxin plays role in many development processes and required by many plant cells for adventitious root formation, swelling of tissue and somatic embryogenesis [41]. Usually, when the concentration of auxin is low, root initiation is favored but when at the high concentration, callus formation occurs [42]. Cytokinins also have important regulative roles involve in an extensive series of physiological and metabolic developments of plants, stimulate cell division, promote flowering and inhibit root cell prolongation [43].

Herbicides are commonly used to control and manage weeds but not to harm pests and organisms living in soil. Usually herbicides have to be selective in action which means capable to kill only certain plants without harming major crops $[23,44,45]$. Dalapon is classified by the U.S. Environmental Protection Agency (USEPA) as a general use of herbicide. According to Dikshith and Diwan [46] Dalapon is a non-color liquid with an acrid odor and it is a kind of acid usually formulates with sodium and magnesium salts. Dalapon contain an active ingredient, 2,2-dichloropropionic acid that had been used widely in Austria, central asia and some parts of the country in the world $[47,48]$.

The purpose of current research is to establish plant tissue culture technique on micropropagation of Nicotiana tabacum L. in order to form shoots and callus. This study includes the effect of Mercuric Chloride $(\mathrm{HgCl} 2)$ on seed surface sterilization. Consequently, cultured leaves and cotyledons explant on MS [42] media at different concentrations of NAA ( $\alpha$-naphthaleneacidic acid) (Auxin) and BAP (6benzylaminopurine) (Cytokinin) under aseptic conditions. Finally, the determination of Dalapon minimum inhibition of tobacco explants will be conducted through spraying method.

\section{Materials and methods}

\subsection{Sterilization of plant materials and seed germination}

Tobacco seeds were provided by Lembaga Tembakau Negera Malaysia. Selected seeds were disinfected with $\left(0.05 \mathrm{gL}^{-1}, 0.2\right.$ $\mathrm{gL}^{-1}, 0.5 \mathrm{gL}^{-1}$ and $\left.1.0 \mathrm{gL}^{-1}\right)$ of Mercuric Chloride ( $\left.\mathrm{HgCl} 2\right)$. Each exposure was three minutes and then the seeds were washed with sterilized water for at least three times with two minutes each. Then the seed were allowed to grow on standard growth media under pathogen-free conditions by supplying $16 / 8 \mathrm{~h}$ (light/dark) at room temperature $\left(25 \pm 2^{\circ} \mathrm{C}\right)$.

\subsection{Preparation of growth regulator for callus induction and shoot regeneration}

The sterilized explants i.e leaves and cotyledons were grown on an MS media supplemented with plant growth regulators at different concentrations of $\alpha$-naphthaleneacidic acid (NAA) $\left(0.1 \mathrm{mgL}^{-1}, 0.2 \mathrm{mgL}^{-1}, 0.5 \mathrm{mgL}^{-1}, 1.0 \mathrm{mgL}^{-1}\right.$ and $\left.2.0 \mathrm{mgL}^{-1}\right)$ and 6-benzylaminopurine (BAP) $\left(0.0 \mathrm{mgL}^{-1}, 1.0 \mathrm{mgL}^{-1}, 2.0\right.$ $\mathrm{mgL}^{-1}, 3.0 \mathrm{mgL}^{-1}$ and $\left.4.0 \mathrm{mgL}^{-1}\right)$. Cotyledon section and leaves with an approximately $0.5-1 \mathrm{~cm}$ were grown on a primary standard solid MS media under a photosynthetic photon flux density (PPFD) of $26 \mu \mathrm{mol} \mathrm{m}^{-2}$ delivered by cool white fluorescent tubes with a photoperiod of $16 / 8 \mathrm{~h}$ (day/night) at $25 \pm 2^{\circ} \mathrm{C}$. In the medium, these cotyledons were allowed to develop for at least two weeks and leaves for one month for shoot and callus regeneration.

The basic tissue culture experiment had three replicates, with more than 75 explants plated for each batch. For each plate containing MS medium for callus and shoot induction different concentrations of NAA $(0.1,0.2,0.5,1.0$ and 2.0 $\left.\mathrm{mgL}^{-1}\right)$ and $\mathrm{BAP}\left(0.0,1.0,2.0,3.0\right.$ and $\left.4.0 \mathrm{mgL}^{-1}\right)$ were prepared. The $\mathrm{pH}$ of the media was adjusted to $\mathrm{pH} 5.7 \pm 1$ prior to autoclaving for $20 \mathrm{~min}$ at $121{ }^{\circ} \mathrm{C}$. After autoclaving, the MS media was allowed to cool at room temperature. Then, $20 \mathrm{~mL}$ medium was dispensed into culture tube. All culture media were maintained at room temperature for growth. The 
culture media was monitored for shoot production and callus fresh weight per explant at weekly intervals throughout 4 weeks period of time.

\subsection{Application of herbicide Dalapon on Nicotiana tabacum}

Herbicide Dalapon was prepared at different concentrations from $5 \mathrm{gL}^{-1}, 10 \mathrm{gL}^{-1}, 15 \mathrm{gL}^{-1}$ and $20 \mathrm{gL}^{-1}$. Then, the two months old tobacco plant was sprayed with different concentrations of Dalapon and its minimum inhibition/resistancy was monitored.

\section{Results and discussion}

\subsection{Effects of Mercuric Chloride $\left(\mathrm{HgCl}_{2}\right)$ on Survival of Tobacco Seeds}

Table 1 shows the $\%$ of seeds survived when washed with various concentrations of $\mathrm{HgCl}_{2}$. The maximum number of seeds germinated was obtained at $0.05 \mathrm{gL}^{-1}$ of $\mathrm{HgCl}_{2}$. However, seeds washed with $\mathrm{HgCl}_{2}$ at $0.2,0.5$, and $1.0 \mathrm{gL}^{-1}$ were not survived suggesting at higher concentrations of $\mathrm{HgCl}_{2}$ was too toxic to the seeds. Fig. 1 . supported Table 1 showing the total number of seeds placed on MS media. It was 25 seeds per petri dishes with three replicates for each treatment. This observation was in agreement with the findings of Azeem et al. [6], that seed washed with $0.05 \mathrm{gL}^{-1}$ of $\mathrm{HgCl}_{2}$ showed a good growth. At $0.05 \mathrm{gL}^{-1}$ of $\mathrm{HgCl}_{2}$ the seed coat is free from contaminants, without killing the seeds. There are many scientific finding of surface sterilization in tobacco tissue culture using $\mathrm{HgCl}_{2}$. [50].

Table 1. The effects of different concentrations of $\mathrm{HgCl} 2$ on seeds germination. Concentrations above $0.05 \mathrm{HgCl}\left(\mathrm{gL}^{-1}\right)$ inhibit seeds germination

\begin{tabular}{lll}
\hline $\begin{array}{l}\text { Concentrations of } \\
\mathbf{H g C l}_{2} \\
\left.\mathbf{( g L}^{-1}\right)\end{array}$ & $\begin{array}{l}\text { Time } \\
(\mathbf{m i n})\end{array}$ & $\begin{array}{l}\text { Seed } \\
\text { germination } \\
(\mathbf{\%})\end{array}$ \\
\hline 0.05 & 3 & 70 \\
0.2 & 3 & 0 \\
0.5 & 3 & 0 \\
1.0 & 3 & 0 \\
\hline
\end{tabular}

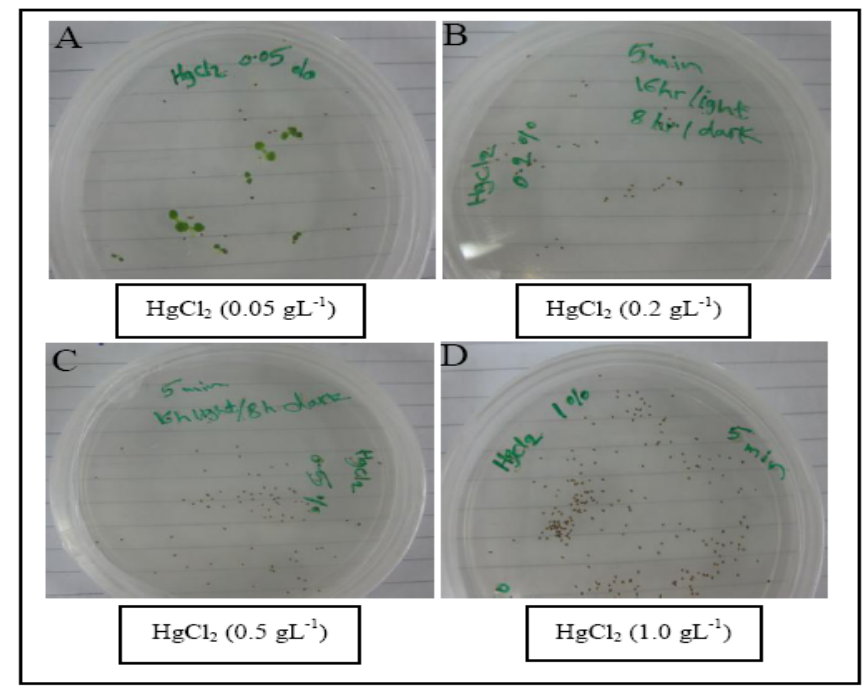

Figure 1: The growth of tobacco seeds after treated with various concentrations of $\mathrm{HgCl}_{2}$; (A) the seeds still showing some growth at $0.05 \mathrm{gL}^{-1}$ of $\left(\mathrm{HgCl}_{2}\right)$. The concentrations of Mercuric Chloride at 0.2, $0.5,1.0 \mathrm{gL}^{-1}$, on plates $B, C$ and $D$, respectively showing no seeds germination after two weeks in culture.

\subsection{Effect of Auxins and Cytokinins on Shoot Formation from Cotyledon Explants}

The purpose of the following experiments were to evaluate the explants (cotyledon and leaves) for their callus and shoot formation at different concentrations of NAA and BAP supplied in MS medium. Cotyledon is important primary explants used, due to their reliability and simplicity for micropropagation [51]. Moreover, in vitro tobacco seed germination needed little period of time to produce cotyledons from seeds in about two weeks. In addition, the combination concentration of plant growth regulators had been applied to find suitable effect of cotyledon explants on shoot/callus formation.

Figure 2 shows the maximum number of shoots (average of $7.66 \pm 0.23$ shoots/explant) per explant (cotyledon) was obtained at combination of both concentrations NAA: BAP, $0.1 \mathrm{mgL}^{-1} \mathrm{NAA}$ and $1.0 \mathrm{mgL}-1 \mathrm{BAP}$, respectively. The minimum shoot per explants was obtained at $0.5 \mathrm{mgL}^{-1} \mathrm{NAA}$ and $0.0 \mathrm{BAP}$. This observation was taken after four weeks of culture. The results seen based on different concentrations of plant growth regulators that had been added into MS media as well as explants type. BAP was essential factor for shoot proliferation, whereas poor shoot development occurred on the media without cytokinins. In fact, certain explants will be more responsive than the others for instance the cotyledon of some species regenerate shoot better than true leaves or stems $[39,52]$. 


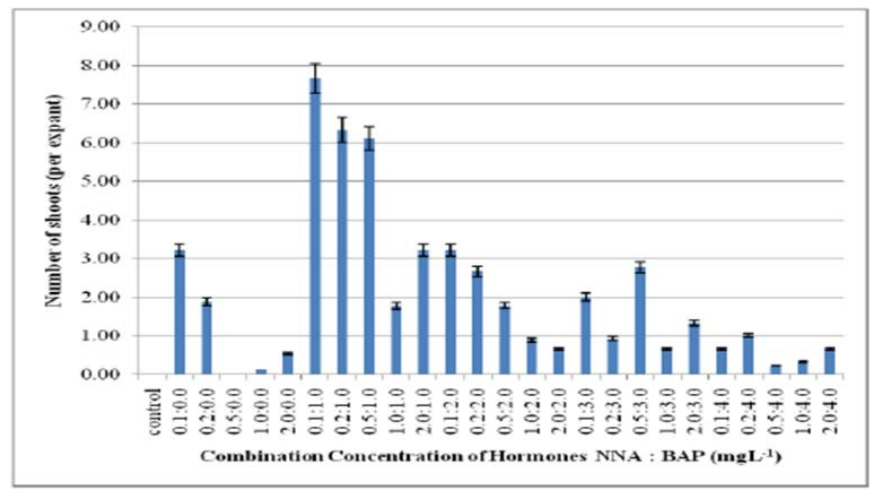

Figure 2. The effects of both NAA and BAP on number of shoots produced per explant in cotyledon culture

3.3. Effect of Combination Concentration of Auxins and Cytokinins on the Mean Callus Weight from Cotyledon Explants

The efficacy of BAP and NAA on callus induction was observed from cotyledon explants. The callus were induced in three weeks by taking cotyledon explants from in vitro grown plants on MS media supplemented with selected concentrations of BAP and NAA. Figure 3 illustrates the highest mean weight of callus formation was $4.02 \mathrm{~g}$ when NAA $0.5 \mathrm{mgL}^{-1}$ : BAP $1.0 \mathrm{mgL}^{-1}$ on MS media. In this experiment, the lowest mean weight of callus was $0.15 \mathrm{~g}$ when supplied by $0.2 \mathrm{mgL}^{-1} \mathrm{NAA}: 3.0 \mathrm{mgL}^{-1}$ BAP. Abaxial surface of leaves disc in touch with media is better than adaxial surface due to a large number of somates on the abaxial surface [53]. Callus formation can be affected by explants type, concentration combination, growth media and type of the plant growth regulators [54].

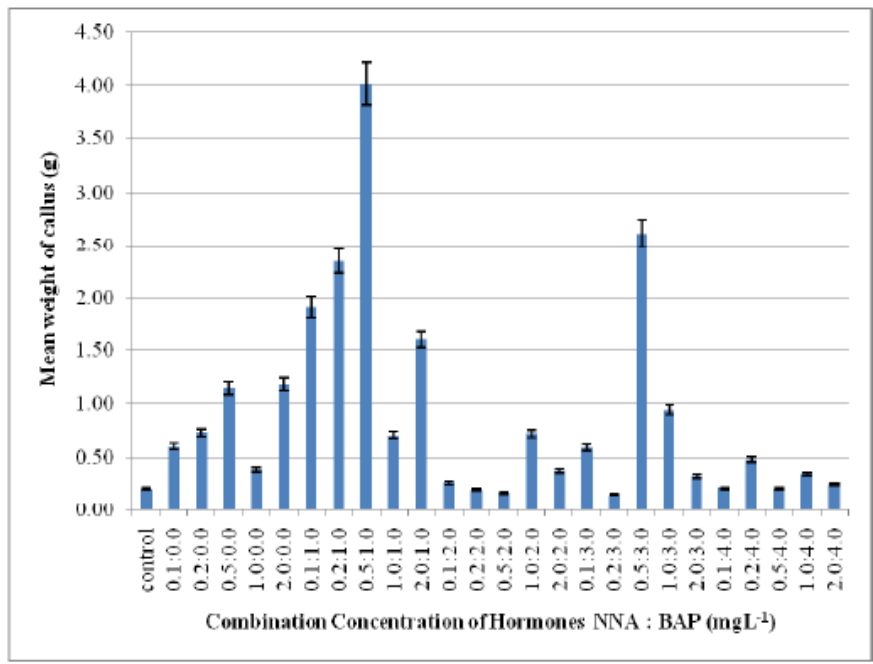

Figure 3 The effects of both NAA and BAP on fresh callus weight gained from cotyledon culture

3.4. Effect of Combination Concentration of Auxins and Cytokinins on the Shoot Formation from Leaf Explant
BAP and NAA were used to investigate the number of shoots induction from leaves culture. The effects of plant growth regulators on shoots proliferation were examined using leaves explant. After four weeks of culture, the numbers of shoots per explants were recorded. Previous study has shown that BAP was one of the most effective among the other cytokinins for inducing shoot development $[55,56]$

Figure 4 shows that the highest numbers of shoots per explants were obtained on the media containing $0.2 \mathrm{mgL}^{-1} \mathrm{NAA}$ and $4.0 \mathrm{mgL}^{-1}$ BAP which produced shoots per explants. This number significantly decreased on media supplemented with NAA $0.1 \mathrm{mgL}^{-1}$ : BAP $3.0 \mathrm{mgL}-1$ that was slightly different from NAA $0.1 \mathrm{mgL}^{-1}$ : BAP $2.0 \mathrm{mgL}-1$ which formed 8.88 and 8.55 number of shoots per explants respectively. On the other hand, the lowest number of shoots per explants were obtained when $0.1 \mathrm{mgL}-1$ NAA: $0.0 \mathrm{mgL}-1$ BAP, $2.0 \mathrm{mgL}-1$ NAA : 0.0 mgL-1 BAP, while $2.0 \mathrm{mgL}-1$ NAA : $2.0 \mathrm{mgL}-1$ BAP resulted in no shoot formation at all.

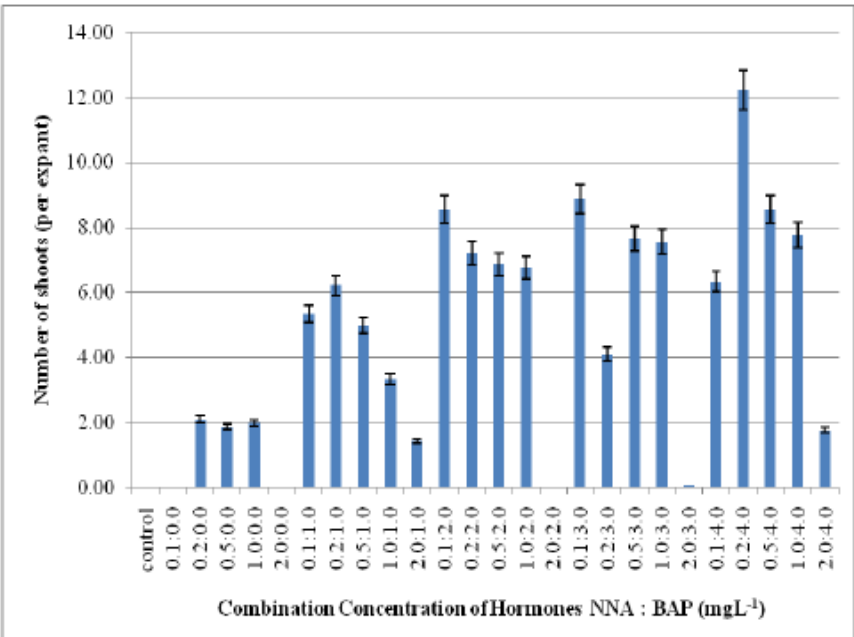

Figure 4 The effects of both NAA and BAP on shoot proliferation from leaves culture

3.5. Effect of Combination Concentration of Auxins and Cytokinins on the Mean Callus Weight from Leaf Explant

Callus induction is significantly depending on explants type. Calli was induced by using leaf explants from in vitro grown plants during four weeks on MS media supplemented with various concentrations of plant growth regulators. Induction in monocots callus requires long time for its initiation [51,57]. Figure 5 shows the highest callus weight was achieved on medium supplemented with hormone combination of 1.0 $\mathrm{mgL}^{-1}$ NAA: $1.0 \mathrm{mgL}^{-1}$ BAP that was $14.8 \mathrm{~g}$ of fresh callus weight. The second best was slightly lower than the previous one that was gained at $2.0 \mathrm{mgL}^{-1} \mathrm{NAA}: 4.0 \mathrm{mgL}^{-1} \mathrm{BAP}$ which recorded only $14.72 \mathrm{~g}$ of fresh callus. However, the lowest fresh callus formation was obtained at $0.1 \mathrm{mgL}^{-1} \mathrm{NAA}: 0.0$ $\mathrm{mgL}^{-1}$ BAP. 
Figure 6 illustrates the effect of Dalapan on tobacco plant after two weeks. Therefore, it was concluded that successful callus formation had been achieved base on plant growth regulators and their combination. The results showed that leaves culture was more efficient to gain better callus fresh weight than using cotyledon culture.

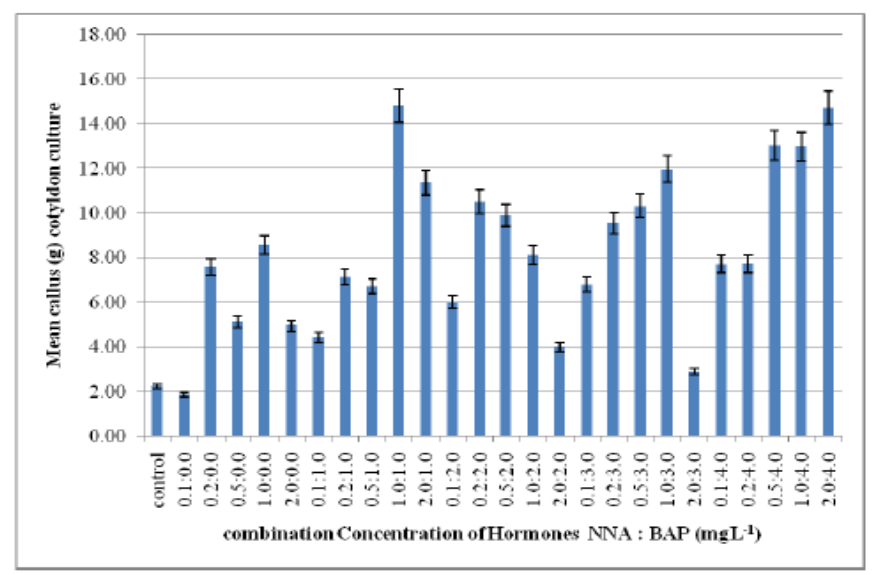

Figure 5. The effects of both NAA and BAP on fresh callus weight gained from leaves culture

\subsection{Effect of Dalapon via spraying method}

Dalapon is a selective herbicide which can only kill the weeds but not directly kill desired plant. The growth of tobacco plant was inhibited using Dalapon at high concentrations. The leaves became bigger but wilt due to the mode of action of Dalapon that affect the plant growth. The uptake of Dalapon was done through the leaves, translocate to other plant tissues.

Table 2. The Effects of various concentrations of herbicide Dalapon on tobacco growth after two weeks in culture

\begin{tabular}{|c|c|c|c|c|}
\hline $\begin{array}{l}\text { Concentrations } \\
\text { of Dalapon }\end{array}$ & $5 \mathrm{gL}^{-1}$ & $10 \mathrm{gL}^{-1}$ & $15 \mathrm{gL}^{-1}$ & $20 \mathrm{gL}^{-1}$ \\
\hline Observations & $\begin{array}{l}\text { Plant Still } \\
\text { remains in } \\
\text { healthy } \\
\text { condition }\end{array}$ & $\begin{array}{l}\text { Leaves } \\
\text { and stems } \\
\text { begin to } \\
\text { change the } \\
\text { color to } \\
\text { yellow }\end{array}$ & $\begin{array}{l}\text { Plants } \\
\text { unable } \\
\text { to } \\
\text { survive }\end{array}$ & $\begin{array}{l}\text { Plants } \\
\text { were } \\
\text { dead }\end{array}$ \\
\hline
\end{tabular}

Table 2 shows several concentrations of Dalapon that had been used and its effect after two weeks in culture. Figure 6 shows that Dalapon at $5 \mathrm{gL}^{-1}$ has no effect on plant after two weeks in culture. Above $5 \mathrm{gL}^{-1}$ of Dalapon showed death to the plant tissue.

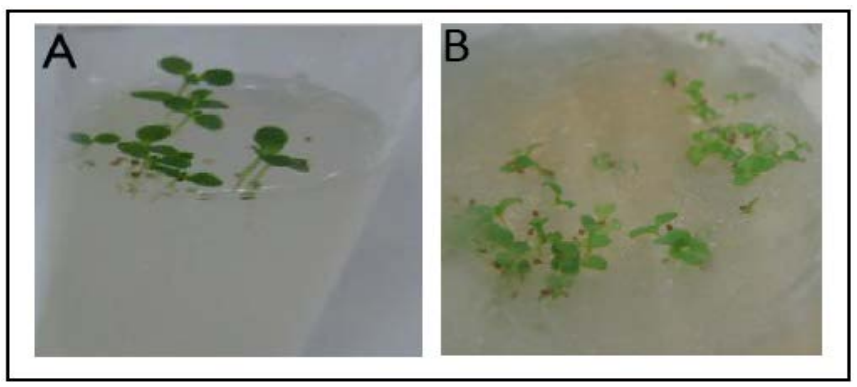

Figure 6 The effect of Dalapon on tobacco plant after two weeks. (A) all plant parts were in a good condition when exposed to $5 \mathrm{gL}^{-1}$ Dalapon. (B) at $10 \mathrm{gL}^{-1}$ Dalapon caused changes in the color of leaves and started to wilt and die

\section{Conclusions}

This study underlined the important technique for tobacco seeds surface sterilization by using Mercuric Chloride $\left(\mathrm{HgCl}_{2}\right)$ at different concentrations. The effects of plant growth regulators on micropropagation of Nicotiana tabacum from cotyledons and leaf explants were established. The micropropagation of two different types of explants showed different number of shoots produced per explants as well as callus fresh weight. Combination of BAP and NAA had been applied to find out the effects on callus fresh weight and number of shoots per explants. Dalapon was also used as herbicide to determine the resistancy of tobacco against Dalapon at minimum inhibition concentration. The establishment of the current study may shed alight in future experiment to transform dehalogenase gene into plant tissue culture for developing plant resistant to herbicide.

\section{Acknowledgment}

We thank Farough Motasemi for checking the analysis. Lastly, the authors offer regards and blessings to all of those who supported this work until completion of the project.

\section{References}

[1]. Bidabadi S.S., Jain S.M., "Cellular, Molecular, and Physiological Aspects of In Vitro Plant Regeneration", Plants, 9, (2020), 702.

[2]. Mohammed S., "Effects and quantity ranges of some auxins on embryogenic callus induction from upland rice cultivars: An overview", International Journal of Life Sciences and Biotechnology, 3(2), (2020), 197204.

[3]. Popova V., Ivanova T., Stoyanova A., Nikolova V., Hristeva T., Zheljazkov V.D., "GC-MS Composition and Olfactory Profile of Concretes from the Flowers of 
Four Nicotiana Species”, Molecules, 25(11), (2020), 2617. https://doi.org/10.3390/molecules25112617.

[4]. Nielsen M.T., "Tobacco. Outlook on Agriculture” 16(2), (1987), 77-81.

[5]. Charlton A.,"Medicinal uses of tobacco in history", Journal of the Royal Society of Medicine, 97(6), (2004), 292-296.

[6]. Azeem S.A, Ullah I., Ali M., Khan A., Bakht J.S.A., "Effects of different sterility on seeds and Callusing frequency as effected by hormones in Nicotiana tabacum L.”, Biofrontiers, 1, (2010), 62-67.

[7]. Gebhardt C., "The historical role of species from the Solanaceae plant family in genetic research", Theoretical and Applied Genetics, 129(12), (2016), 2281-2294.

[8]. Kumar V., Maherchandani N., "Differentiation in callus cultures of a tobacco (Nicotiana tabacum cv. White Burley) variant: some biochemical aspects”, Plant Cell, Tissue and Organ Culture, 14, (1988), 177-185.

[9]. Kaya Y., Yilmaz S., Marakli S., Gozukirmizi N., Huyop F., "Transformation of Nicotiana tabacum with DehE Gene”, Journal of Food Agriculture and Environment, 11(3-4), (2013) ,777-780.

[10]. Kaya Y., Yilmaz S., Gozukirmizi N., Huyop F.,"Evaluation of transgenic Nicotiana tabacum with dehE gene using transposon based IRAP”, American Journal of Plant Sciences, 4, (2013), 41-44.

[11]. Ganapathi T., Suprasanna P., Rao P.S., Bapat V., "Tobacco (Nicotiana tabacum L.)-A model system for tissue culture interventions and genetic engineering”, Indian Journal of Biotechnology, 3, (2004), 171-184.

[12]. Ma J.K., Drossard J., Lewis D., Altmann F., Boyle J., Christou P., Cole T., "Regulatory approval and a firstin-human phase I clinical trial of a monoclonal antibody produced in transgenic tobacco plants", Plant Biotechnology Journal, 13(8), (2015), 1106-1120.

[13]. Habibi P., Daniell H., Soccol C.R., Grossi-de-Sa M.F., "The potential of plant systems to break the HIV-TB link” Plant Biotechnology Journal, 17(10), (2019), 1868-1891.

[14]. Phan H.T., Pohl J., Floss D.M., Rabenstein F., Veits J., Le B.T., Chu H.H., Hause G., Mettenleiter T., Conrad U., "ELPylated haemagglutinins produced in tobacco induce potentially neutralizing antibodies against H5N1 virus in mice”, Plant Biotechnology Journal, 11, (2013), 582-593.

[15]. Zhong X., Qi G., Yang J., Xing G., Liu J., Yang X., "High-efficiency expression of a receptor-binding domain of SARS-CoV spike protein in tobacco chloroplasts” Sheng Wu Gong Cheng Xue Bao 30(6), (2014), 920-930.

[16]. Demurtas O.C, Massa S., Illiano E., De Martinis D., Chan P.K, Di Bonito P., Franconi R., “Antigen production in plant to tackle infectious diseases flare up: The case of SARS”, Frontiers in Plant Science, 7, (2016), 54-57.

[17]. Yan M.M., Xu C., Kim C.H., Um Y.C., Bah A.A., Guo D.P., "Effects of explant type, culture media and growth regulators on callus induction and plant regeneration of Chinese jiaotou (Allium chinense)", Scientia Horticulturae”, 123(1), (2009),124-128.

[18]. Gourguillon L., Rustenholz C., Lobstein A., Gondet L., "Callus induction and establishment of cell suspension cultures of the halophyte Armeria maritima (Mill.) Willd”, Scientia Horticulturae, 233, (2018), 407-411.

[19]. Mehmood F., Abdullah U.Z., Shahzadi I., Ahmed I., Waheed M.T., Poczai P., Mirza B., "Plastid genomics of Nicotiana (Solanaceae): insights into molecular evolution, positive selection and the origin of the maternal genome of Aztec tobacco (Nicotiana rustica)", Peer Journal, 8, (2020), e9552.

[20]. Olmstead R.G., Bohs L., Migid H.A., Santiagovalentin E., "Molecular phylogeny of the Solanaceae", Molecular Phylogenetics and Evolution, 57, (2008), 1159-1181.

[21]. Dupin J., Matzke N.J., Särkinen T., Knapp S., Olmstead R.G., Bohs L., Smith S.D., "Bayesian estimation of the global biogeographical history of the Solanaceae", Journal of Biogeography, 44(4), (2016), 887-899.

[22]. Suzuki K., Ichiro Y., Nobukazu T., “Tobacco plants were transformed by Agrobacterium rhizogenes infection during their evolution”, The Plant journal, 32, (2002), 775-787.

[23]. Kaya Y., Marakli S., Gozukirmizi N., Mohamed E., Javed M.A., Huyop F., "Herbicide Tolerance Genes Derived from Bacteria”, The Journal of Animal and Plant Sciences, 23(1), (2013), 85-91. 
[24]. Kanwal M., Joyia F.A., Mustafa G., Zia M.A., Rana I. A., Khan M.S., "Direct in vitro regeneration of Nicotiana plumbaginifolia L. and the potential for genetic transformation”, International Journal of Horticulture, 7(6), (2017), 40-46.

[25]. Liu H., Kotova T.I., Timko M.P., “Increased leaf nicotine content by targeting transcription factor gene expression in commercial flue-cured tobacco (Nicotiana tabacum L.)”, Genes(Basel), 10(11), (2019), 930-935.

[26]. Sun H, Sun X, Wang H, \& Ma X., “Advances in salt tolerance molecular mechanism in tobacco plants", Hereditas,157(5), (2020),1-6.

[27]. Makenzi N.G., Mbinda W.M., Okoth R.O., Ngugi M.P., "In vitro plant regeneration of sweet potato through direct shoot organogenesis", Journal of Plant Biochemistry and Physiology, 6(1), (2018), 207-210.

[28]. Latifian E., Arvas Y.E., Kaya Y., "Tagetes minuta bitkisinin mikro üretimi üzerinefarklı BAP ve IAA konsantrasyonlarının etkileri”, International Journal of Life Sciences and Biotechnology,1(2), (2018), 96-104.

[29]. Kaya Y., Karakutuk S., "Effects of different growth regulators on regeneration of Turkish upland rice", Anadolu Tarım Bilimleri Dergisi 33(3), (2018), 226231.

[30]. Aboshama H.M., Atwa M.M., "In vitro Evaluation of Somaclonal Variation of Two Potato Cultivars Santana and Spunta for Resistance against Bacterial Blackleg Pectobacterium atrosepticum”, Journal of Plant Biochemistry \& Physiology, 7(3), (2019), 243-253.

[31]. Mangena P., "Benzyl adenine in plant tissue culturesuccinct analysis of the overall influence in soybean [Glycine max (L.) Merrill.] seed and shoot culture establishment”, Journal of Biotech Research, 11, (2020), 23-34.

[32]. Hussein N.B.M., Huyop F., Kaya Y., "An easy and reliable method for establishment and maintenance of tissue cultures of Nicotiana tabacum cv. TAPM 26", International Journal of Science Letters, 2(2), (2020), 62-71.

[33]. Kutty P.C., Parveez G.K.A., Huyop F., “An easy method for Agrobacterium tumefaciens-mediated gene transfer to Nicotiana tabacum cv. TAPM26", Journal of Biological Sciences, 10(6), (2010), 480-489.
[34]. Kutty P.C., Parveez G.K.A., Huyop F., “Agrobacterium tumefaciens-infection strategies for greater transgenic recovery in Nicotiana tabacum cv. TAPM26”, International Journal of Agricultural Research”, 6(2), (2011), 119-113.

[35]. Geethalakshmi S., Balakrishnan H., Natarajan S., "Optimization of media formulations for callus induction, shoot regeneration and root induction in Nicotiana benthamiana”, Journal of Plant Science \& Research, 3(1), (2016), 150-154.

[36]. Eibl R., "Plant cell culture technology in the cosmetics and food industries : current state and future trends", Applied Microbiology and Biotechnology, 102(20), (2018), 8661- 8675.

[37]. Al-remi F., Arvas Y.E., Durmuş M., Kaya Y.,’Tomato Plant and Its In Vitro Micropropagation”, Journal of Engineering Technology and Applied Sciences, 3(1),(2018), 57-73.

[38]. Arvas Y.E., Aksoy H.M., Kaya Y., "Patates bitkisinde biyoteknolojik çalışmalar”, International Journal of Life Sciences and Biotechnology, 1(1), (2018), 37-47.

[39]. Ali G., Fazal H., Zahir A., Muhammad T., Muhammad A.K., "Callus Induction and in vitro Complete Plant Regeneration of Different Cultivars of Tobacco (Nicotiana tabacum L.) on Media of Different Hormonal Concentrations”, Biotechnology, 6, (2007), 561-566.

[40]. Vissenberg K., Feijo J.A., Weisenseel M.H., Verbelen J. P., "Ion fluxes, auxin and the induction of elongation growth in Nicotiana tabacum cells”, Journal of Experimental Botany, 52, (2001), 2161-2167.

[41]. Eklof S., Astot C., Sitbon F., Moritz T., Olsson O., Sandberg G., "Transgenic tobacco plants co-expressing Agrobacterium iaa and ipt genes have wild-type hormone levels but display both auxin- and cytokininoverproducing phenotypes”, The Plant Journal, 23(2), (2000), 279-284.

[42]. Skoog F., Miller C.O., "Chemical regulation of growth and organ formation in plant tissues cultured in vitro", Symposia of the Society for Experimental Biology, 54, (1957), 118-130.

[43]. Allawzi M., Kandah M.I., "Parametric study of biodiesel production from used soybean oil”, European Journal of Lipid Science and Technology, 110, (2008), 760-767. 
[44]. Duke S.O., Scheffler B.E., Boyette C.D., Dayan F.E., "Biotechnology in weed control. In: Kirk-Othmer encyclopedia of chemical technology” Wiley, New York, pp 1-25, (2015).

[45]. Beckie H.J., Ashworth M.B., Flower K.C., "Herbicide resistance management: recent developments and trends”, Plan Theory, 8(6), (2019),161-167.

[46]. Dikshith T.S., Diwan P.V., Industrial Guide to Chemi and Drug Safety, (2003), John Wiley\&Sons,Inc.

[47]. Hawker D.W., Cumming J.L., Watkinson A., Bartkow M.E., "The occurrence of the herbicide dalapon (2,2dichloropropionate) in potable water as a disinfection by-product”, Journal of Environmental Monitoring, 13(2), (2011), 252-256.

[48]. Akcay K., Yilmaz K., "Isolation, characterization and molecular identification of a halotolerant Bacillus megaterium CTBmeg1 able to grow on halogenated compounds”, Biotechnology \& Biotechnological Equipment, 33:1, (2019), 945-953, DOI: 10.1080/13102818.2019.1631717.

[49]. Arvas Y. E., \& Kaya Y., "Genetiği değiştirilmiş bitkilerin biyolojik çeşitliliğe potansiyel etkileri" Yüzüncü Y1l Üniversitesi Tarım Bilimleri Dergisi, 29(1), (2019), 168-177.

[50]. Neelu J., "In vitro growth and shoot multiplication in Nicotiana tabacum L.-Influence of gelling agent and carbon source”, International Journal of Plant Developmental Biology, 3(1), (2009), 23-29.
[51]. Mehmood F., "Effect of different parameters on transformation and regeneration of nodal and leaf explants of Nicotiana tabacum cv. Petiat Havana. “ Master thesis, (2016)., Quaid-i-Azam University, Islamabad, Pakistan.

[52]. Monthony A.S., Page S.R., Hesami M., Jones A.M.P., "The Past, Present and Future of Cannabis sativa Tissue Culture”, Plants (Basel, Switzerland), 10(1), (2021), 110, DOI: 10.3390/plants10010185.

[53]. Dhaliwal H.S., "Competence and determination during Shoot and Root Organogenesis in vitro” Master of Science Thesis, (1998), University of Calgary, Canada.

[54]. Attfield E.M., Evans P.K., "Developmental pattern of root and shoot organogenesis in cultured leaf explants of Nicotiana tabacum”, Journal of Experimental Botany, 42, (1991), 51-57.

[55]. Stolarz A., Macewicz J., Lörz H., "Direct somatic embryogenesis and plant regeneration from leaf explants of Nicotiana tabacum L.”, Journal of Plant Physiology, 137(3), (1991), 347-357.

[56]. Vajjiram C., Vanitha A., Kalimuthu K., "Ftir and gc-ms analysis of bioactive compounds in ethanol extract of tobacco callus (Nicotiana tabacum)", World Journal of Pharmaceutical Research, 6(14), (2017), 530-545.

[57]. Gelvin S.B., “Agrobacterium-Mediated Plant Transformation: the Biology behind the "GeneJockeying” Tool”, Microbiology and molecular biology reviews, 67(1), (2003), 16-37. 